\title{
EFL Learners' English Speaking Difficulties and Strategy Use
}

\author{
Ming-yueh Shen (Corresponding author) \\ Dept. of Applied Foreign Languages, National Formosa University \\ 64 Wunhua Road, Huwei,Yun-lin, Taiwan, R.O.C. \\ Tel: 886-05-6315819Ｅ-mail: myshen@nfu.edu.tw
}

Tzu-yen Chiu

Dept. of Applied Foreign Languages, National Formosa University

64 Wunhua Road, Huwei, Yun-lin, Taiwan, R.O.C.

Tel: 886-05-6315819 E-mail: tychiu@nfu.edu.tw

Received: August 23, 2019

doi:10.5296/elr.v5i2.15333
Accepted: October 12, 2019 Published: October 15, 2019

URL: https://doi.org/10.5296/elr.v5i2.15333

\begin{abstract}
This study aimed to explore the factors that caused the EFL learners' English speaking difficulties and then investigate the successful learners' strategy use to improve their English speaking performance. A five-level Likert-scale questionnaire was conducted to anonymously investigate 148 EFL sophomore and junior English majors in Taiwan. Results of the analysis showed that (a) psychological problems (e.g. nervousness, fear of making mistakes, and lack of confidence) was the primary reason for English speaking difficulties, followed by linguistic problems (e.g. insufficient vocabulary), and environmental problems (e.g. lack of learning context for English conversation); (b) a majority of successful learners tended to use various speaking strategies to improve their English speaking performance and particularly focused on linguistic accuracy by repeatedly practicing the pitch, pronunciation, and intonation. Furthermore, most of them seized the chances to practice speaking English, such as joining English social activities, or participating in English speech contests etc. They also used the body language (e.g. facial expressions, eye contacts, and gestures) for better communication. The findings suggest pedagogical implications for promoting the EFL learners' speaking English.
\end{abstract}

Keywords: English speaking, difficulties, strategy use, EFL learners 


\section{Introduction}

English speaking seems intuitively to be the most important skill compared to the others (Ur, 1996). Language for communication has been globally recognized by the EFL learning context as an essential skill, as noted by Graddol (2006) that the use of English as a tool for international communication has obviously been continuing for several decades. For instance, Luoma (2004) emphasized the importance of spoken performance of a language is becoming more prominent because the ability to speak a language reflects a person's personality, self-image, knowledge of the world, ability to reason, skill to express thoughts in real time. Al-Abri (2008) showed that the Ministry of Education in Oman advocated developing the young learners' English communication skills for critical thinking and science technology (Al-Abri, 2008). English speaking ability was emphasized as a necessary skill to develop for both the workplace and the academic fields.

Despite its important roles for learners' development, speaking English poses challenge for most EFL learners. In Ur's study (1996), those common difficulties include inhibition and nothing to say. Zhang (2009) further indicated such challenges as worries about making mistakes, fears for criticism, or shyness. When it comes to the class activities, Zhang (2009) also suggested that low or uneven participation was a problem in a speaking course.

In addition to investigating the EFL learners' common difficulties in speaking English, several studies indicated that oral language development has largely been neglected in the classroom, and frequently, oral language in the classroom is used more by teachers than by students (Hosni, 2014). This phenomenon is in serious contradiction to the notion that the major goal of all English language teaching should enhance learners' ability to use English effectively and accurately in communication (Davies \& Pearse, 2000). Other studies indicated that regardless of their length of study in the foreign country, most of the ESL learners still felt challenged when utilizing English for academic work (Lee, 2009; Sawir, 2005). Sawir (2005) interviewed twelve international students in Australia and found that they all had difficulties in English communication even though they were studying in Australia for years. In Asia, where English is not an official language, most of the EFL learners lack the opportunity to speak English, although courses for English speaking practice have been arranged in the school curriculum. Generally speaking, most EFL learners are afraid of speaking English in the public. This frustrating information necessitates rethinking what causes those Asian learners' difficulties in speaking English and how we can do to help solve the problems.

While several previous studies have examined the oral performance of Asian international students in the ESL context, however, there is little research on how difficult EFL learners feel to participate orally in class discussions when learning in the EFL learning context. How can we help EFL learners? Thus, the purpose of this study was first to investigate English speaking difficulties experienced by EFL college learners. A further investigation was to examine what strategies their successful peer learners used to communicate more effectively and efficiently. The results of data analyses hoped to provide helpful implications for more effective course design. Additionally, this study hoped to provide the struggling EFL learners some effective strategies to help them overcome speaking difficulties.

Specifically, the research questions were addressed as follows: 


\section{Macrothink}

1). What speaking difficulties did EFL learners encounter when speaking English?

2). What kinds of speaking strategies were used by the successful learners?

\section{Literature Review}

\subsection{English Speaking Difficulties in ESL /EFL Language Learning}

The importance of speaking competence for second or foreign language communication has been underlined for decades; however, research has shown that either ESL or EFL learners find it challenging to speak a foreign language. Sawir (2005) investigated ESL learners' learning difficulties, by interviewing twelve international students in Australia, including Indonesia, Hong Kong, Thailand, Vietnam and Japan. All the interviewed participants admitted that communicating in English had been difficult even though they were studying in Australia for years. Similarly, Lee (2009) revealed that regardless of their length of study in the US, all of the interviewed graduates in her study felt challenged to participate in whole class discussions. Hosni (2014) also emphasized that EFL learners, no matter how much they know about English, still face speaking difficulties.

Rababa'h (2005) suggested that learner factors, teaching strategies, curriculum, and environment result in difficulties in speaking English. After analyzing speaking difficulties of the freshmen in Muhammadiyah University of Malang in Indonesia, Lukitasari (2008) found that the learners revealed speaking difficulties such as inhibition or nothing to say, due to not being able to master three elements of speaking namely vocabulary, grammar and pronunciation. This finding is consistent with that in Shayna (2003) which indicated the EFL learners who want to improve speaking skills need four interlocked skills, including listening, vocabulary, pronunciation and confidence. In addition, Lee (2009) explored those factors that influenced six Korean graduates' oral classroom participation in the US. Data analyses from formal and informal interviews and class observations pointed that multilayered factors, such as learners' English proficiency, different sociocultural values, and classroom environment, were intertwined.

Hosni (2014) investigated speaking difficulty by observing grade 5 learners in the elementary schools in Oman. The results of her study are similar to those of Lukitasari (2008) revealing three aspects including linguistic difference, mother tongue use, and inhibition. The EFL learners in her study were struggling to find accurate vocabulary to speak English. They also had problem on assembling sentence which lead them to use their mother tongue. Besides, due to limited speaking opportunities, learners were afraid of speaking English, felt embarrassed about making mistakes, and worried about being criticized or laughed by others. As a result, they usually avoided speaking in class so that their participation was very low.

Previous research suggested that both the psychological and linguistic difficulties (i.e. inadequate vocabulary and mastery of syntax to speak in another language) cause learners a great deal of obstacles in speaking. In recent years, Ozkan, Bada, and Genc (2011) asserted the importance of pronunciation in speaking skill because people compete with limited time while speaking to recall words, and also need to take care of their pronunciation. Lin (2013) further suggested that in addition to insufficient vocabulary, negative psychological reactions also involved, i.e., anxiety and fear, being afraid of making mistakes. Due to those concerns, they might worry about misunderstandings and thus avoid some English speaking occasions. 
Moreover, mental problem also let EFL learners feel difficult in speaking. As shown in MacIntyre, Clément, Dörnyei, and Noels's (1998), learners' willingness to communicate was determined partly by their self-confidence. They reached a conclusion that self-confidence affected significantly on EFL learners' oral performance.

Recently, Sayuri (2016) investigated the English speaking difficulties of the EFL learners at Mulawarman University in Indonesia by conducting speaking test and questionnaires from the first to the fourth semester. The results found that those students still felt confused to make conversation, deliver statements, and give opinions in English even if they were speaking English in each speaking course. Besides those difficulties, the researcher observed that they also had difficulties in vocabulary, pronunciation, grammar usage, and lack of self-confidence. These findings support those found in Shayna's (2003), Lukitasari's (2008), and MacIntyre, et al. (1998).

However, enough vocabulary and confidence is not the single element which helps speaking English well. For instance, according to Nunan (1999), the speaker needs communicative competence which includes not only linguistic competence but also a range of other sociolinguistic and conversational skills which help him/ her know how to say what to whom and when.

\subsection{English Speaking Strategies in ESL/EFL Language Learning}

In spite of various speaking difficulties involved in EFL learners' English speaking, previous researchers found that the successful EFL learners have their own strategies to improve their speaking ability. Learning strategies are the conscious thoughts and behaviors used by learners to help them better understand, learn, and remember the SL/FL information (O'Malley \&Chamot, 1990). Previous research has indicated that learning strategy can enhance learners' language acquisition and help them conquer difficulties in learning (Dina \& Ghadeer, 2014; Sayuri, 2016; Yang, 2014). This implies that in order to become fluent in English speaking, EFL learners must know speaking strategies and learn to use them effectively.

Trudgill (1992) suggested the following processes: (i) collect ideas; (ii) arrange them in the best sequence; (iii) choose the language in which he has to communicate with others. Learners apply these habits in the use of their mother-tongues or foreign languages to face their audience with confidence. Analyzing the data collected from those successful learners, Razmjoo and Ardekani (2011) indicated seven distinct categories of learner strategies: (a) interference of mother tongue;(b) error correction;(c) accuracy; (d) body language and substitution; (e) educational-aid methods and instruments;(f) memorization and summary; (g) sensitivity toward chances. Moreover, accurate pronunciation is another important strategy for speaking English well. Speakers have to consider not only the pronunciation of the individual words, but also the connection between the words in the sentence. Moreover, Gan (2012) noted that in some social situations, use of colloquial language might be helpful when people face a shortage of vocabulary and can't express accurately for what they want to say.

Lin (2013), working on the adult learners' perceptions, difficulties, and strategy preferences of orally communication in English, restated three types of communication strategies in this study-i.e., metacognitive, cognitive, and socio-affective. Metacognitive strategies refer to 
methods used to help students understand the way they learn; in other words, it means processes designed for students to 'think' about their 'thinking.' Cognitive strategy is one type of learning strategy that learners use in order to learn more successfully. Socio-affective strategies are learning strategies concerned with managing emotions, both negative and positive. The relationship between affective strategies and learning is not clear, but a positive affective environment helps learning in general.

Furthermore, a recent research by Yang (2014) suggested effective strategies to help improve learner's oral communication. Those strategies are summarized as follow: (a) watching the news in English instead of Chinese; (b) seek out lectures in English on topics of interest to you and try to take notes; (c) watch for plays or dramatic performances given in English on campus; (d) choose a famous person whose accent you admire, and imitate the way he or she speaks; (e) find a friend or two and agree to speak English at certain regular times. Yang (2014) indicated that the learners in his study used these strategies to improve their oral communication skills with less fear of making mistakes in the public.

\section{Methodology}

\subsection{Participants}

The participants were 156 sophomore and junior English majors at a technical university in the central Taiwan. They were chosen for the reason that they all learned English as a foreign language and had more English speaking training courses during the second and third academic year. For the second purpose of this study, 60 participants were selected as more successful learners in speaking English. A successful performer was defined according to his /her average score over 80 out of 100 in the previous academic year. In addition, they were found to have more fluent speaking and better vocabulary ability, with confidence while speaking. Following being asked about what difficulties they experienced in speaking English, how they used strategy to improve their speaking performance was examined as well.

\subsection{Questionnaire}

This five-level Likert-scale questionnaire was divided into two parts to firstly investigate speaking difficulties of EFL learners in English and then the strategies used by the successful learners. The first part, which is underpinned by the combination of notions by Nation and Newton (2009), as well as Krashen (2003), asked for speaking difficulties related to linguistic, psychological, and learning environment. Nation and Newton (2009) suggested four types of factors including time pressure, planning, the standards of performance, and the amount of support. Moreover, Krashen (2003) indicated a variety of affective variables, i.e., motivation, self-confidence, and anxiety. To help the EFL students to evaluate their difficulties in linguistic ability for speaking English, this study designed such items as insufficient vocabulary, poor English grammar, and difficulty in organizing sentences, etc. (See Appendix I, Part I, items 1, 2, 3, 4, 5, 6). Psychological factors include the question items such as peer pressure, lack of confidence, timidity, and so on (See Appendix I, Part I, items 7, 8, 9, 10, 11, $12,13)$. With regard to the learning environment factors, those items involve lack of practice, contests, and learning context, etc. (See Appendix I, Part I, items 14, 15, 16, 17, 18).

The second part of the questionnaire, theoretically supported by O'Malley and Chamot (1990), Knapp and Hall (2006), Razmjoo, Ghasemi and Ardekani (2011), was divided into six 
sections: L1 assistance, linguistic accuracy, body Language use, educational-media instruments, memorizing useful expressions, and self-upgrading. With respect to being assisted by the mother tongue, those strategies involved organizing ideas and writing down responses with native language before responding in English (See Appendix I, Part II, items 1, $2,3,4)$. Those strategies for linguistic accuracy consisted of improving the intonation and vocabulary size of English in the leisure time (See Appendix I, Part II, items 5, 6, 7, 8). Furthermore, using body language such as gestures and eye contacts were listed as the strategies for effective communication (See Appendix I, Part II, items 9, 10, 11). Additionally, those strategies about using the educational-media instruments included those such as watching films, and planning studying aboard (See Appendix I, Part II, items 12, 13, 14, 15). Those strategies for memorizing useful expressions included memorizing the daily dialogs, and using synonyms (See Appendix I, Part II, items 16, 17, 18). As for those strategies about seizing the chances of self-upgrading, they comprised of actively talking to foreigners, or forcing oneself to participate in English discussions (See Appendix I, Part II, items 19, 20, 21, $22,23,24)$.

\subsection{Data Collection and Analysis}

The participants were asked to fill out the close-ended questionnaire within 10 to 15 minutes. The Chinese edition of this questionnaire was used to avoid any possible linguistic misunderstanding. Among them, 8 uncompleted copies were dropped out and 148 copies were remained as valid questionnaires. Microsoft Office Excel 2010 was conducted for data analysis. For each measure, percentage was used to determine the overall patterns of the EFL learners' English speaking difficulties and speaking strategy uses.

To analyze the EFL learners' difficulties in speaking English, the analysis focused on the items that were indicated as "strongly agree "and "agree". The difficulties each student revealed were identified and interpreted based on factors involved in each item, for example, linguistic factors, psychological factors, and learning environment. We identified the most difficult factor of English speaking from the data with the highest percentage. The results were presented by pie charts and Tables including percentages.

Then, the data from the five-point-scale speaking strategy questionnaire were analyzed as five points for "strongly agree" and one point for "strongly disagree." The students indicated "strongly agree" showing that they perceived using the strategy all the time, or "strongly disagree" revealing using the strategy none of the time. The strategy with the highest percentage was recognized as that mostly used by successful learners. To provide a more concise and comprehensible pattern of the participants' answers to the questionnaire, the first two alternatives ('strongly agree' and 'agree') were combined for analysis and so were the last two ('disagree' and 'strongly disagree'). The results were shown by percentage, pie charts, and Tables.

\section{Results and Discussion}

\subsection{The EFL Learners' Difficulties in Speaking English}

Table 1, Table 2, and Table 3 present the EFL learners' difficulties in English speaking relating to the linguistic and psychological difficulties as well as learning environment. As shown in Table 1, a majority of the learners agreed that insufficient vocabulary ( $83 \%)$ was 
their predominant difficulty in English speaking, followed by insufficient expressions (64.9\%), talking intermittently (60.8\%), and weak sentences organization (52.7\%). However, it was interesting to find that poor grammar (37.8\%) and inaccurate pronunciation $(46.6 \%)$ did not annoy the learners as much as the others. Those findings support Baker and Westrup's (2003) which suggested it is difficult for many students to respond when the teachers ask them to say something in a foreign language because they have little ideas about what vocabulary to use, or how to use the grammar correctly.

Table 1. Linguistic Factors for English speaking difficulties for the EFL learners

\begin{tabular}{lllll}
\hline & & $\mathrm{SA}+\mathrm{A}$ & $\mathrm{U}$ & $\mathrm{D}+\mathrm{SD}$ \\
\hline 1. Insufficient vocabulary & $83.1 \%$ & $12.8 \%$ & $4.1 \%$ \\
2. Insufficient grammar & $37.8 \%$ & $45.3 \%$ & $16.9 \%$ \\
3. Inaccurate pronunciation & $46.6 \%$ & $37.2 \%$ & $16.2 \%$ \\
4. Insufficient expressions & $64.9 \%$ & $20.9 \%$ & $14.2 \%$ \\
5. Talking intermittently & $60.8 \%$ & $27.0 \%$ & $12.2 \%$ \\
6. & Insufficient sentences organization & $52.7 \%$ & $31.1 \%$ & $16.2 \%$ \\
\hline
\end{tabular}

Table 2 shows psychological factors for the EFL learners in English speaking, revealing that a majority of them responded that nervousness (73\%), fear of making mistakes $(70.9 \%)$, and lack of confidence $(64.9 \%)$ were the main causes of English speaking difficulties. Those findings were consistent with MacIntyre, Clément, Dörnyei, and Noels' (1998) which mentioned the effects of self-confidence on the learners' oral performance, stressing that the learners' willingness to communicate was determined partially by their self-confidence. The results also supported Park and Lee (2005) who examined the relationships between L2 learners' anxiety, self-confidence and oral performance. In addition, more than half of the EFL learners (55.4\%) reported their annoyance about not being able to be understood or being misunderstood during the oral practice in English, which might cause their psychological barrier in English speaking. On the contrary, less than half of the learners in this study kept the neutral attitude toward the peer pressure $(37.8 \%)$, the stuttering $(42.6 \%)$, and the timidity and low volume (33.1\%). One possible reason might be that the learners considered the peer pressure to be less intimidating because they have been familiar with each other for years.

Table 2. Psychological factors for English speaking difficulties for the EFL learners

\begin{tabular}{lllll}
\hline & & $\mathrm{SA}+\mathrm{A}$ & $\mathrm{U}$ & $\mathrm{D}+\mathrm{SD}$ \\
\hline 7. Fear of making mistakes & $70.9 \%$ & $18.2 \%$ & $10.8 \%$ \\
$8 . \quad$ Peer pressure & $37.8 \%$ & $38.5 \%$ & $23.6 \%$ \\
9. & Nervousness & $73.0 \%$ & $19.6 \%$ & $7.4 \%$ \\
\hline
\end{tabular}


10. Stuttering

$42.6 \%$

$38.5 \%$

$18.9 \%$

11. Lack of confidence

$64.9 \%$

$25.0 \%$

$10.1 \%$

12. Worries about not being understood

$55.4 \%$

$24.3 \%$

$20.3 \%$

13. Timidity and low volume

$33.1 \%$

$35.1 \%$

$31.8 \%$

In addition, Table 3 reveals that poor learning environment also results in difficulty in speaking English. The results demonstrated that a majority of the EFL learners $(85.1 \%)$ were not satisfied with their learning environment due to lack of opportunity for English conversation. Besides, most of them revealed other poor learning environment such as less support from school authority (54.1\%) and insufficient material resources (48\%). The findings added support to those indicated in Lukitasari's (2008) which found that the EFL learners faced such speaking problems as inhibition, nothing to say, low or uneven participation and mother tongue use. We assumed that the EFL learning context without English-only environment might cause the EFL learners in this study become anxious to speak English. In other words, the less practice they have for speaking English, the more anxious they become.

Table 3. Learning environment factors for English speaking difficulties for the EFL learners

\begin{tabular}{lllll}
\hline & & $\mathrm{SA}+\mathrm{A}$ & $\mathrm{U}$ & $\mathrm{D}+\mathrm{SD}$ \\
\hline 14. & Infrequent English conversation & $85.1 \%$ & $10.8 \%$ & $4.1 \%$ \\
15. & Learning Environment with less support & $54.1 \%$ & $35.8 \%$ & $10.1 \%$ \\
16. & Insufficient practice & $37.8 \%$ & $41.9 \%$ & $20.3 \%$ \\
17. & Insufficient resources & $48.0 \%$ & $38.5 \%$ & $13.5 \%$ \\
18. & Low participation in class & $35.8 \%$ & $39.9 \%$ & $24.3 \%$ \\
\hline
\end{tabular}

Figure 1 conclusively presents the difficulties the EFL learners experienced in speaking English. Generally speaking, $38.4 \%$ of the participants considered psychological factors as their primary barrier to affect their speaking English, followed by the linguistic problems (35.1\%) and learning environment (26.5\%). Overall, there was no distinct difference between the three factors that caused the learners' English speaking difficulties. However, relatively more of the students indicated the psychological factors as their difficulty in speaking English, when compared with others. Psychological factor appeared as the main difficulty for the EFL learners when speaking in English. This finding is in line with Horwitz (1986) who acknowledged that L2 learners may be so anxious that they perform poorly in L2 because of cognitive or first language disabilities or both. He argued vehemently, however, that such anxiety reaction can interfere with language learning. 


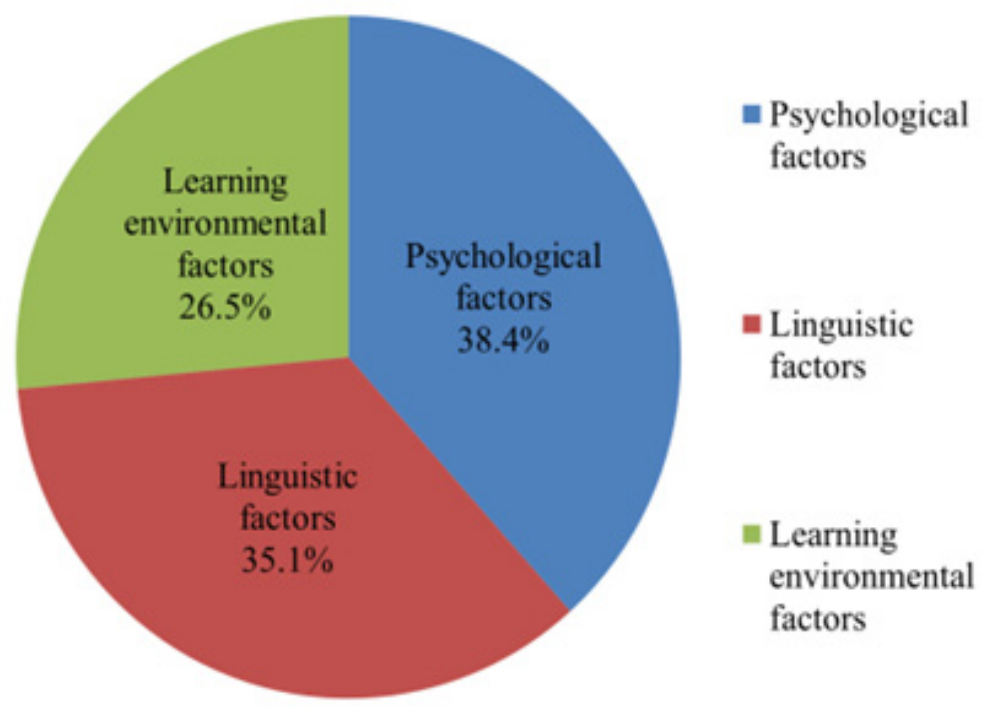

Figure 1. The EFL learners' difficulties in speaking English

\subsection{Strategies Used by the EFL Successful Learners}

Furthermore, a further analysis was conducted to examine how each of the six categories of strategy was used by the successful EFL learners, as shown from Table 4 to Table 9. With regard to the strategy about "L1 assistance" in Table 4, over 60 percent of the successful learners expressed that they tended to comprehend the conversation with the help of their native language (63.3\%), i.e., organizing their idea first and then expressed it in English $(63.3 \%)$. The results suggest that those successful learners used their mother tongue as an assistance, even though L1 might interfere L2 learning. As shown by Razmjoo and Ardekani (2011), compared with the others, fewer of the learners used L1 as a strategy, because the learners' mother tongue interferes with the speaking process as translation from one's mother tongue into English. This might be a possible reason to explain why EFL learners put less focuses on the process of translating and writing down responses $(23.4 \%)$. Overall, this finding is consistent with that in Figure 2, showing that compared with all the other speaking strategies, the strategy of "L1 assistance" was used by fewer students (15.1\%).

Table 4. L1 Assistance used by the EFL successful learners as speaking strategies

\begin{tabular}{llll}
\hline & $\mathrm{SA}+\mathrm{A}$ & $\mathrm{U}$ & $\mathrm{D}+\mathrm{SD}$ \\
\hline $\begin{array}{l}\text { 1. Understanding other person's } \\
\text { words with L1 before answering }\end{array}$ & $63.3 \%$ & $20.0 \%$ & $16.7 \%$ \\
$\begin{array}{l}\text { 2. Organizing ideas with L1 } \\
\text { 3. Translating English into L1 }\end{array}$ & $63.3 \%$ & $23.3 \%$ & $13.3 \%$ \\
4. Writing down responses in L1 & $46.7 \%$ & $30.0 \%$ & $23.3 \%$ \\
\hline
\end{tabular}


In the section for "Linguistic accuracy" in Table 5 especially, a majority of the successful EFL learners agreed that the intonation $(73.3 \%)$, practicing pitch and pronunciation $(81.7 \%)$ were the most important strategies for linguistic accuracy. Also, more than half of the successful learners considered "English grammar" (56.7\%) and "vocabulary size" (60\%) to be helpful for their English speaking.

Table 5. Linguistic accuracy used by the EFL successful learners as speaking strategies

\begin{tabular}{lllll}
\hline & & $\mathrm{SA}+\mathrm{A}$ & $\mathrm{U}$ & $\mathrm{D}+\mathrm{SD}$ \\
\hline 5. & English grammar & $56.7 \%$ & $36.7 \%$ & $6.7 \%$ \\
6. Minding the intonation & $73.3 \%$ & $26.7 \%$ & $0.0 \%$ \\
7. & Practicing pitch and pronunciation & $81.7 \%$ & $16.7 \%$ & $1.7 \%$ \\
8. Increase the vocabulary size & $60.0 \%$ & $38.3 \%$ & $1.7 \%$ \\
\hline
\end{tabular}

Moreover, when it came to using the body language as a strategy, Table 6 revealed that the successful EFL learners used body language including gesture $(66.7 \%)$, eye contact $(75 \%)$, and facial expression (76.6\%), to enhance their speaking performance. The results suggest that the successful EFL learners were able to use their body language to assist their speaking sufficiently, as indicated by Razmjoo and Ardekani (2011).

Table 6. Body language used by the EFL successful learners as speaking strategies

\begin{tabular}{llll}
\hline & $\mathrm{SA}+\mathrm{A}$ & $\mathrm{U}$ & $\mathrm{D}+\mathrm{SD}$ \\
\hline 9. Gesture & $66.7 \%$ & $33.3 \%$ & $0.0 \%$ \\
10. Eye contact & $75.0 \%$ & $23.3 \%$ & $1.7 \%$ \\
11. Facial expression & $76.3 \%$ & $20.3 \%$ & $3.4 \%$ \\
\hline
\end{tabular}

As for the strategy of "using Educational-Media Instruments" in Table 7, "watching films" (68.3\%) and "studying aboard" $(61.7 \%)$ were the two main strategies used by the successful EFL learners to improve their English speaking performance, as shown in Table 3. The findings add support to the previous study conducted by David (2002) who showed that parents, teachers, media personnel and decision-makers all acknowledge that media has a role to play in developing greater critical awareness among listeners, viewers and readers.

Table 7. Educational /media instruments used by the EFL successful learners as speaking strategies

\begin{tabular}{llll}
\hline & SA $+\mathrm{A}$ & $\mathrm{U}$ & $\mathrm{D}+\mathrm{SD}$ \\
\hline 12. Watching films & $68.3 \%$ & $25.0 \%$ & $6.7 \%$ \\
13. Reading English newspaper or magazine & $35.0 \%$ & $46.7 \%$ & $18.3 \%$ \\
\hline
\end{tabular}


14. Studying aboard as exchange students

$61.7 \%$

$28.3 \%$

$10.0 \%$

15. Participating English summer camp

$41.7 \%$

$38.3 \%$

$20.0 \%$

In addition, as for using memorized expressions in Table 8, most of the successful EFL learners revealed that they memorized the daily dialogs $(66.7 \%)$, and used synonyms $(65 \%)$ to enhance their expressions. However, it was surprising to find that fewer of them participated in English summer camp (41.7\%) and read English newspaper or magazine $(35 \%)$.

Table 8. Memorizing expressions used by the EFL successful learners as speaking strategies

\begin{tabular}{llll}
\hline & $\mathrm{SA}+\mathrm{A}$ & $\mathrm{U}$ & $\mathrm{D}+\mathrm{SD}$ \\
\hline 16. Memorizing the daily dialogs & $66.7 \%$ & $30.0 \%$ & $3.3 \%$ \\
17. Using synonyms & $65.0 \%$ & $33.3 \%$ & $1.7 \%$ \\
18. Using transitional words & $58.3 \%$ & $33.3 \%$ & $8.3 \%$ \\
\hline
\end{tabular}

The last part in Table 9 illustrated how the learners in this study used the strategy of "seize the Chances of Self -Upgrading" to improve their English speaking. Some of the successful EFL learners tried upgrading their English speaking by "participating in the social activities" (50\%), "talking to the foreigners" (46.6\%), "talking to oneself in English" (46.6\%), and "giving a comment in class" (48.3\%). However, only few of them used the strategies such as "having a conversation with friends" (16.7\%) and "volunteering for contests" (15\%) to enhance their English speaking. One possible reason might be that the learning environment cannot provide the atmosphere of speaking English and the opportunities for speaking English.

Table 9. Self - Upgrading used by the EFL successful learners as speaking strategies

\begin{tabular}{llll}
\hline & $\mathrm{SA}+\mathrm{A}$ & $\mathrm{U}$ & $\mathrm{D}+\mathrm{SD}$ \\
\hline 19. Participating in social activities & $50.0 \%$ & $45.0 \%$ & $5.0 \%$ \\
20. Talking to foreigners & $46.7 \%$ & $45.0 \%$ & $8.3 \%$ \\
21. Talking to oneself in English & $46.7 \%$ & $40.0 \%$ & $13.3 \%$ \\
22. Giving a comment in class & $48.3 \%$ & $41.7 \%$ & $10.0 \%$ \\
23. Having a conversation with friends & $16.7 \%$ & $63.3 \%$ & $20.0 \%$ \\
24. Volunteering for contests & $15.0 \%$ & $50.0 \%$ & $35.0 \%$ \\
\hline
\end{tabular}

Figure 2 conclusively presents the percentages for the six categories of speaking strategies used by the successful learners in the study. Generally, the results indicated no obvious discrepancy between the six strategies as shown in Figure 2. In other words, the results 


\section{Macrothink}

suggest that the successful EFL learners used various strategies to improve their English speaking performance. However, compared with others, being aware of linguistic accuracy was the primary strategy the successful learners used when speaking English (20.8\%). This finding lent support to Razmjoo and Ardekani (2011), who indicated that the strategy that almost all learners repeatedly elaborated on was "accuracy" in their speech. In other words, to communicate successfully, the successful learners pay more attention to accuracy than fluency. They emphasize grammar, intonation, pitch and pronunciation. To improve their English speaking, most of the successful learners put more efforts on linguistic accuracy than the others.

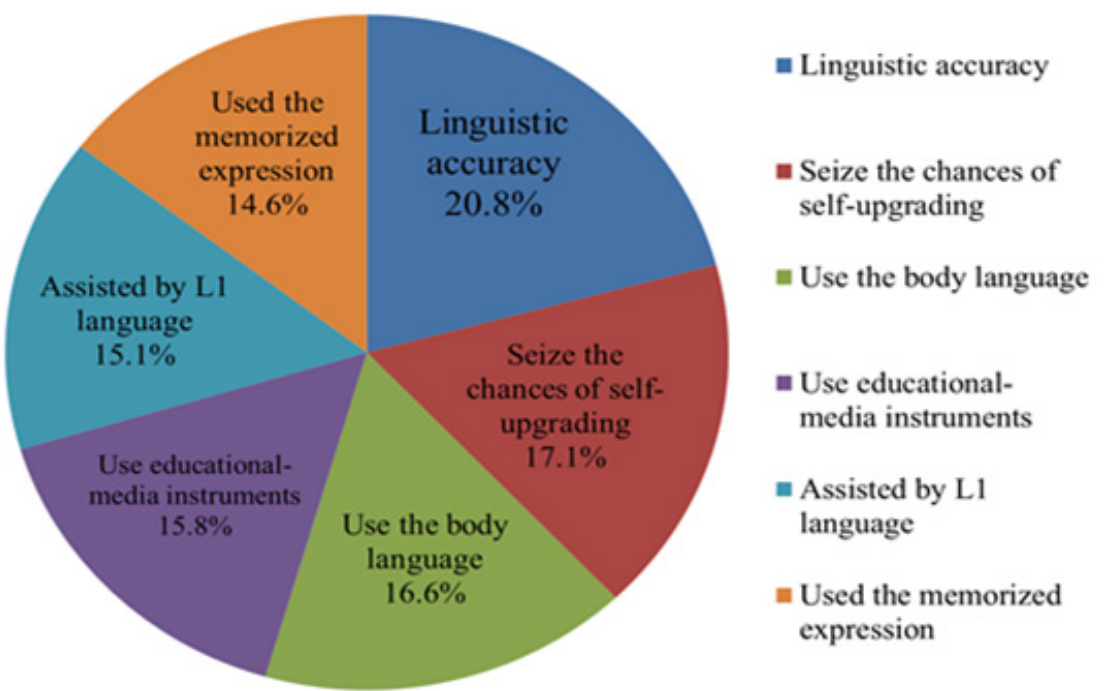

Figure 2. Strategies used by the EFL successful

In addition, the successful EFL learners used other strategies such as seizing the chances of self-upgrading (17.1\%), using L1 language, and using the body language (16.6\%), followed by using educational-media instruments $(15.8 \%)$, assisted by L1 language (15.1.\%). In this study, however, fewer learners used the memorized expressions (14.6\%). This finding was in line with Razmjoo and Ardekani's (2011) which suggested that some learners preferred giving summaries instead of memorizing dialogs. As shown in Figure 2, this might be the reason for why the successful learners put focus less on using memorized expressions because they might believe if they could speak with near native-like intonation and pronunciation, they would feel more proud and become more confident to communicate with other people. In conclusion, the scattered results suggest that the successful EFL learners used various strategies to improve their English speaking. Among the suggested strategies, the successful EFL learners revealed that they paid more attention to linguistic accuracy, i.e., accuracy in vocabulary, grammar, pronunciation, intonation, pitch, etc.

\section{Conclusion, Pedagogical Implications, and Suggestions for the Future Research}

The results of this study indicated that most of the EFL learners considered psychological factors, such as "nervousness" and "fear of making mistakes," as the main barrier in speaking English. For the EFL learners, "insufficient vocabulary" was the predominant problem that 
caused their difficulty in English speaking. The learning environment with less English conversation also seriously worsened their performance in speaking English. Furthermore, the results showed that most of the successful EFL learners in this study pay more attention to "linguistic accuracy" to enhance their speaking performance by putting more efforts to practicing intonation and pronunciation. Additionally, they also focused on body languages, such as "eye contact" and "facial expression," as other effective ways to improve their speaking ability.

The results from investigating the EFL learners' English speaking difficulties and strategy use give rise to several suggestions for improving L2 speaking instruction. Firstly, to alleviate the psychological factors, the teachers in the oral training courses should create more opportunities for the EFL learners to express themselves, so that the pressure of speaking in public could be relieved. Teachers should design drama activities to increase entertainment atmosphere, which helps motivate the learners to speak English. Moreover, the EFL learners should force themselves to speak English in their leisure time and actively participate in all kinds of English speaking competitions. Moreover, the learners should expand their vocabulary size as much as possible to help English speaking. Finally, the official institute should develop a more effective English speaking environment by inviting more foreigner students to join the learning context, which the EFL learners could have more opportunities to communicate with the English-speaking friends. In addition, teachers should arrange the group contest, instead of individual participation, to reduce the learners' anxiety for speaking English. That is, if the EFL learners are encouraged to take part in a group, they may be more willing to join the contests.

This study offers an important insight to the EFL teachers for a better understanding of English speaking difficulties and the useful strategies that the successful learners used for a better speaking performance. However, the results should be interpreted cautiously because the students' retrospective report on the use of strategies may have caused them to reveal those they may not have actually used, due to the quantitative nature of the research method. In an attempt to collect a more in-depth data, an interview method and class observation should be conducted as a supplementary approach in the future research to examine the actual use of strategies. Therefore, there is a critical need for in-depth, qualitative explorations to provide rich descriptions of how the EFL learners feel about participating in English verbally.

\section{References}

Al-Abri, K. (2008). Teachers' Evaluation of EFL Textbooks Used in the Omani Basic Education Schools (Unpublished master's thesis). ELT Curriculum and Methodology, College of Education. Sultan Qaboos University.

Baker, J., \& Westrup, H. (2003). Essential Speaking Skills: A Handbook for English Language Teachers. London: Continuum.

Davies, P., \& Pearse, E. (2000). Success in English Teaching. Oxford: Oxford University Press

Dina, Al \& Ghadeer, Al. (2014). An investigation of the difficulties faced by EFL undergraduates in speaking skills, English Language Teaching, 7(1), 19-27. https://doi.org/10.5539/elt.v7n1p19 


\section{Macrothink}

Gan, Z. (2012). Understanding L2 speaking problems: Implications for ESL curriculum development in a teacher training institution in Hong Kong, Australian Journal of Teacher Education, 37(1), 43-59. https://doi.org/10.14221/ajte.2012v37n1.4

Graddol, D. (2006). English Next. British: The English Company. Ltd.

Hosni, S. (2014). Speaking difficulties encountered by young EFL learners. International Journal on Studies in English Language and Literature (IJSELL), 2(6), 22-30.

Knapp, M., \& Hall, J. (2006). Nonverbal communication in human interaction. Belmont, CA: Thomson Wadsworth.

Krashen, S. (2003). Explorations in language acquisition and use: The Taipei lectures. Portsmouth, NH: Heinemann.

Lee, G. (2009). Speaking up: Six Korean students' oral participation in class discussions in US graduate seminars. English for Specific Purposes, 28(3), 142-156 https://doi.org/10.1016/j.esp.2009.01.007

Lin, H. (2013). Perception, difficulties, and strategy preferences of English oral communication for Taiwanese college students. Thesis and Dissertations on English Teaching and Learning in Taiwan, 38(2), 159-182

Luoma, S. (2004). Assessing speaking. Cambridge: Cambridge University Press. https://doi.org/10.1017/CBO9780511733017

Lukitasari, N. (2008). Students' Strategies in Overcoming Speaking Problems in Speaking Class. University of Muhammadiyah Malang.

MacIntyre, P. D., Dörnyei, Z., Clément, R., \& Noels, K. (1998). Conceptualizing willingness to communicate in a L2: A situation model of L2 confidence and affiliation. Modern Language Journal, 82, 545-562. https://doi.org/10.1111/j.1540-4781.1998.tb05543.x

Nation, I. S. P., \& Newton, J. (2009). Teaching ESL/EFL listening and speaking. ESL \& applied linguistics professional series. UK: Routledge Taylor \& Francis Group. https://doi.org/10.4324/9780203891704

Nunan, D. (1999). Second Language Teaching \& Learning. Heinle \& Heinle Publishers: An International Thompson Publishing Company, Boston, Massachusetts 02116 USA.

Ozkan, Y., Bada, E., \& Genc, B. (2011). Speak the Real: News Articles as Major Source for Oral Competence. David, J.A. English as a Second Language: Languages and Linguistics. New York: Nova.

O'Malley, J. M., \& Chamot, A. U. (1990). Learning Strategies in Second Language Acquisition. Cambridge, U.K.: Cambridge University Press. https://doi.org/10.1017/CBO9781139524490

Rababa'h, G. (2005). Communication problems facing Arab learners of English. Journal of Language and Learning, 3(1), 1-22.

Razmjoo, S., \& Ardekani, S. (2011). A model of speaking strategies for EFL learners, The Journal of Teaching Language Skills (JTLS), 3(3), 115-142.

Sayuri, S. (2016). English Speaking Problems of EFL Learners of Mulawarman University. Indonesian Journal of EFL and Linguistics, 1(1), 47-61. https://doi.org/10.21462/ijefll.v1i1.4 


\section{Macrothink

Sawir, E. (2005). Language difficulties of international students in Australia: The effects of prior learning experience. International Education Journal, 6(5), 567-580.

Shayna, O. (2003). English speaking tips for 4 common difficulties. Retrieved from https://www.espressoenglish.net/english-speaking-tips-for-4-common-difficulties

Trudgill, P. (1992). Sociolinguistics: An introduction. UK: Penguin Book Ltd.

Ur, P. (1996). A course in language teaching: Practice and theory. Cambridge: Cambridge University Press. https://doi.org/10.2991/icelaic-14.2014.84

Yang, Z. (2014). Strategies of improving spoken English for learners. Beijing: Atlantis Press.

Zhang, S. (2009). The role of input, interaction, and output in the development of oral fluency. English Language Teaching, 2(4), 91-100. https://doi.org/10.5539/elt.v2n4p91

\section{Copyright Disclaimer}

Copyright reserved by the author(s).

This article is an open-access article distributed under the terms and conditions of the Creative Commons Attribution license (http://creativecommons.org/licenses/by/3.0/). 